\title{
Relationship between body condition score on the service per conception and conception rate of Brahman Cross cows
}

\author{
Mohamad Ervandi ${ }^{* 1)}$, Moh. Nur Ihsan ${ }^{2)}$, Sri Wahjuningsih' ${ }^{2)}$, Aulia Puspita Anugra Yekti' ${ }^{2)}$, \\ Trinil Susilawati ${ }^{2}$ \\ ${ }^{1)}$ Faculty of Agricultural Sciences, Muhammadiyah University of Gorontalo \\ 2) Department of Animal Production, Faculty of Animal Science, University of Brawijaya
}

Submitted: 10 November 2019, Accepted: 03 March 2020

\begin{abstract}
The factors that influence the success of Artificial Insemination is affected by acceptors that will be used for AI which have a good Body Condition Score, because BCS has a relationship with animal reproduction, such as fertility and pregnancy. The purpose of this research was to evaluate and determine the relationship of Body Condition Score (BCS) on Service per Conception (S/C) and Conception Rate (CR). The material used was 80 Brahman Cross (BX) cows, the sample was selected by Purposive Sampling with the criteria 2-3 years old with body weight ranged from 300-500 kg, gave birth, and BCS between 4-7 (scale 1-9). The method used in this study was the survey method. The variables observed were the relationship between Body Condition Score (BCS), Service per conception (S/C), and Conception Rate (CR). The data was obtained by using correlation analysis and also a simple regression with the SPSS 2.0 software program, then analyzed descriptively. The results showed that the equation of relationship between BCS and S/C variables obtained $\mathrm{r}=0.961 \%$ and the regression value equation $\mathrm{y}=-25.998+1.520 \mathrm{x}(\mathrm{R} 2) 23.9 \%$. The relationship between BCS and CR variables obtained a value of $r=0.976 \%$ and BCS regression equation value with $C R y=-39.727+1.109 x\left(R^{2}\right) 29.5 \%$. The research thus concludes that there is a positive relationship that is being between BCS on the S/C and CR of Brahman Cross cows.
\end{abstract}

Keywords: artificial insemination; cattle breeding; regression analysis; reproduction

*Corresponding author: ervandi_husain@yahoo.co.id 


\section{INTRODUCTION}

Artificial insemination (AI) is a technology that has been proven to increase livestock populations and also improve genetic quality, especially in Indonesia (Yekti, et al., 2017 ${ }^{\mathrm{a}}$ ). The success of AI implementation is influenced by several factors, among others, female livestock physiology, heat detection, semen handling, semen quality of inseminator skills, accuracy AI timing, Body Condition Score (BCS) of livestock health is mainly related to reproductive organs (Susilawati, 2013). Breeding is closely related to the level of productivity and reproduction of livestock. Many factors that affect reproduction include the quality of estrous, the number of mating per pregnancy or Service per Conception (S/C), pregnancy rates based on the Non-Return Rate (NRR) method, Conception Rate (CR) and assessment of body condition or Body Condition Score (BCS). Yekti, et al., $\left(2017^{\mathrm{b}}\right)$, explained that the success of AI is also influenced by BCS conditions which indicate the level condition of animal body fat. BCS was used to evaluate feeding management, assess individual animal health status and reproductive efficiency (Noakes, 2001).

The body condition score is related to the reproduction of livestock, which is directly related to livestock breeding, such as fertility, pregnancy, giving birth process, and lactation - basically, animal body size, female age, sex, and genetic affect reproductive organs. Overweight females can cause reproductive disorders and metabolic diseases. On the other hand, a lack of weight can cause a disturbance in reproductive organs. Kuswati and Susilawati (2016) state that body weight gain is not only influenced by genetic factors but also environmental factors, mainly feed, which causes variations in body weight gain.

The female BCS (Body Condition Score) is one of the requirements to consider in AI (Ahuja and Montiel, 2005). The ideal BCS of cows for AI is 3.5-4 on a scale of $1-5$. BCS $\leq 2.5$ on scale $1-5$ was an expression of malnutrition, one of the deficiencies of function and the reduction of fertility (Noakes, 2001; Ahuja and Montiel, 2005; Roelofs et al., 2010). In addition to BCS, inseminated cows should be healthy, especially for reproductive organs, and have a normal estrus cycle (Saacke, 2008).

Therefore, BCS is important for maintenance and breeding management to increase the number of cattle populations both on breeding companies and farmers. The pregnancy success rate can be observed from Conception Per Service (S/C) and CR (Conception Rate) using NRR (Non-Return Rate).

\section{MATERIALS AND METHOD Materials}

The material used was 80 Brahman Cross (BX) cows. The sample was selected by Purposive Sampling and included weight $300-500 \mathrm{~kg}$, a normal estrus cycle, have BCS between 4-7 years (1-9 scale).

\section{Method}

The method used in this study was the survey method. Samples of Brahman Cross cows had been maintained at the Breeding Unit of PT. Pasir Tengah District of Cianjur, West Java. Samples data was taken from one population including Body Condition Score (BCS), primary data collection, Service per Conception (S/C), and Conception Rate (Susilawati 2013; Jainudeen and Hafez 2008; Royal et al., 2000) S/C and NRR can be formulated as follows:

$$
\begin{aligned}
& \mathrm{S} / \mathrm{C}=\frac{\text { Number of AI dosage }}{\text { Number of pregnancy }} \\
& \mathrm{CR}=\frac{\text { Number of pregnancy on fisrt AI }}{\text { Total of all females on the AI }} \times 100 \% \\
& \text { The data obtained were analyzed } \\
& \text { using simple correlation and regression } \\
& \text { with SPSS 20 Software program and then } \\
& \text { analyzed descriptively. }
\end{aligned}
$$




\section{RESULTS AND DISCUSSION Relationship of Body Condition Score (BCS) to Service per Conception (S/C)}

The relationship of Body Condition Score (BCS) to Service per Conception $(\mathrm{S} / \mathrm{C})$ in various treatments was shown in Table 1. The S/C value of BCS 4, 5, 6 and 7 were 2.91; 2.85; 2.77; and 1.66 respectively. Each BCS group had a different $\mathrm{S} / \mathrm{C}$ value. Based on the results of the analysis obtained, the value of the correlation coefficient of the relationship between BCS and S/C variables was $\mathrm{r}=0.961 \%$, which had gives a positive relationship that is being contribution $(\mathrm{P}>0.05)$. The calculation of the determination coefficient $\left(\mathrm{R}^{2}\right)$ was $23.9 \%$. This means that S/C $23.9 \%$ were influenced by BCS, and the rest is influenced by other factors. The relationship between BCS and $\mathrm{S} / \mathrm{C}$ can be expressed in the regression equation $\mathrm{Y}=-25.984+1.520 \mathrm{X}$, which means that BCS can be used as an S/C estimator where each increase of 1 unit of BCS was followed by an increase in S/C of $1.520 \%$. This value indicates that Brahman Cross cows' fertility was still considered not good because when cows were inseminated, it needs 2-4 times service.

Table 1. Service per Conception in various BCS groups

\begin{tabular}{lccccc}
\hline & \multicolumn{5}{c}{ BCS } \\
\cline { 2 - 5 } & 4 & 5 & 6 & 7 & $\mathrm{P}$ \\
\cline { 2 - 5 } & $(\mathrm{n}=31)$ & $(\mathrm{n}=23)$ & $(\mathrm{n}=21)$ & $(\mathrm{n}=5)$ & \\
\hline Service per Conception (times) & 2.91 & 2.85 & 2.77 & 1.66 & $\mathrm{P}>0.05$ \\
\hline
\end{tabular}

The high S/C value in this study was due to Brahman Cross cows experiencing Silent heat and also Repeat Breeder, which causes early embryo death and also caused by reproductive disorder on Brahman Cross cows. Susilawati, et al., (2018) state that the problem that occurs in breeding BX was the number of cases of Silent heat in Brahman Cross that make it difficult for farmers and inseminators to detect the estrus period and determine the timing of AI implementation correctly. Jainudeen and Hafez (2008) mentioned that non-pregnant cattle could experience repeated mating (repeat breeders) caused by embryonic death, abortion, and fetal mummification. Repeat breeder occurs due to errors in breeding management and also the presence of infectious diseases that interfere with reproductive performance. Furthermore, Yekti, et al., (2017 $\left.{ }^{\mathrm{b}}\right)$ suggest that embryonic death was generally caused by two factors, namely the virus and also management factors generally are due to malnutrition, because lack of feed or obesity will cause embryonic death. Normal S/C values range from 1.6 to 2.0
(Jainudeen and Hafez, 2008; Susilawati, 2013). S/C values were influenced by nutrition and animal weight (Hoque et al., 2003). Lack of nutrition and poor condition of BCS can cause reduced fertility in cows. The reproductive fertility of cows was influenced by nutrients obtained by cows and played an important role in the reproductive cycle (Pradhan, 2008). Hypernutrients in which rations were given excessively result in obese animals, excess fat tissue was formed so that reproductive organs are not optimal (Jainudeen and Hafez, 2008). In contrast, Yekti, et al. $\left(2017^{b}\right)$ found that the condition of hyponutrients in which the composition of feed rations was low and did not meet the needs and also deficiencies of minerals, vitamins, or proteins which resulted in the reproductive system of livestock not running normally.

Relationship of Body Condition Score (BCS) to Conception Rate (CR)

The relationship of the Body Condition Score (BCS) to the Conception Rate (CR) in various treatments was shown in Table 2. 
Table 2. Conception Rate in various BCS groups

\begin{tabular}{lccccc}
\hline & \multicolumn{5}{c}{ BCS } \\
\cline { 2 - 5 } & 4 & 5 & 6 & 7 & $\mathrm{P}$ \\
\cline { 2 - 5 } & $(\mathrm{n}=31)$ & $(\mathrm{n}=23)$ & $(\mathrm{n}=21)$ & $(\mathrm{n}=5)$ & \\
\hline Conception Rate $(\%)$ & $12.5 \%$ & $5 \%$ & $8.75 \%$ & $3.75 \%$ & $\mathrm{P}>0.05$ \\
\hline
\end{tabular}

The CR value on BCS 4, 5, 6 and 7 were $12.5 \% ; 5 \% ; 8.75 \%$ and $3.75 \%$ respectively. Each BCS group has a different $\mathrm{CR}$ value. Based on the results of the analysis obtained the value of the correlation coefficient of the relationship between BCS and CR variables obtained $\mathrm{r}$ $=0.976 \%$, which had gives a positive relationship that is being contribution $(\mathrm{P}>0.05)$. The calculation of the determination coefficient (R2) was $29.5 \%$. This means that $29.5 \%$ of $\mathrm{CR}$ was influenced by BCS, and the rest was influenced by other factors. The relationship between $\mathrm{BCS}$ and $\mathrm{CR}$ can be expressed in the regression equation $\mathrm{Y}=$ $39.727+1.109 \mathrm{X}$, which means that BCS can be used as a CR estimator where each increase in a unit of BCS is followed by an increase in CR of $1.109 \%$.

The results of this study indicate that a low CR value is caused by Brahman Cross cattle having interference with their reproductive organs, especially in the ovaries that experience ovary hypofunction, cystic follicles, and abnormalities in their reproductive organs, especially in the cervix and uterus. Hafez and Hafez (2008) suggested that anestrus due to ovarian hypo-function was often associated with failure of follicular cells to respond to hormonal stimuli, changes in quantity and quality of hormonal secretions, decreased stimulation associated with the function of the hypothalamus-pituitary in the ovary which will cause decreased gonadotropin secretion, so there is no ovarian activity after giving birth. Saacke (2008) suggests that nutritional deficiencies can result in reduced fertility.

If a nutrient deficiency occurs in livestock, then automatically, the livestock will experience production and reproduction problems, this will also affect the fertility rate of BX cows. Nutrition also affected the level of conception on the success of the AI (Roche, 2006). The sufficient Body Condition Score (BCS) of females that will be inseminated is a requirement that needs to be considered (Montiel, and Ahuja 2005; Carneiro et al., 2011). Pryce, et al., (2001) stated that BCS could be used as a management and selection tool to improve reproductive performance.

Disorders of the reproductive organs due to obesity with indications of high BCS or due to disease, causing reduced fertility in livestock (Yekti, et al., 2017 ${ }^{\mathrm{b}}$ ). Ibtisham, et al. (2018) lack of nutrition will affect the imbalance of reproductive hormones, which causes ovulation inhibition and will affect the success of the AI. In addition to $\mathrm{BCS}$, females that will be inseminated should be healthy, especially in the reproductive tract, and have a normal estrus cycle (Saacke, 2008).

\section{CONCLUSION}

Based on the results of the study, it can be concluded that the Body Condition Score has a positive relationship the being to the value of S/C and also the number of Conception Rate (CR) of Brahman Cross cows.

\section{ACKNOWLEDGMENT}

Researchers would like to say thank you to BUDI-DN Scholarship in collaboration with the Education Funding Management Institute (LPDP Ministry of Finance of the Republic of Indonesia) as research funders as well as the Director and Company Staff of PT. Pasir Tengah (PT. Widodo Makmur Perkasa), which had been facilitated this research. 


\section{REFERENCES}

Carneiro, L. C., Campos, C. C., \& Dos Santos, R. M. (2012). Timed artificial insemination and early diagnosis of pregnancy to reduce breeding season in Nelore beef cows. Tropical Animal Health and Production, 44(3), 623627. https://doi.org/10.1007/s11250011-9945-7

Hafez, E. S., \& Hafez, B. (2008). Reproductive Cycle. In Reproduction in Farm Animals. Blackwell Publishing.

Hoque, M. A., Salim, H. M., Debnath, G. K., Rahman, M. A., \& Saifuddin, A. K. M. (2003). A study to evaluate the Artificial Insemination (AI) success rate in cattle population based on three years record among different sub-centers of chittagong and cox's bazar district of Bangladesh. Pakistan Journal of Biological Sciences, 6(2), 105-111. https://doi.org/10.3923/pjbs .2003 .105 .111

Ibtisham, F., Nawab, A., Li, G., Xiao, M., An, L., \& Naseer, G. (2018). Effect of nutrition on reproductive efficiency of dairy animals. Medycyna Weterynaryjna, 74(1), 6025-2018. https://doi.org/10.21521/ mw. 6025

Jainudeen, M., \& Hafez, E. S. (2008). Reproductive Failure in Females (B. Hafez \& E. S. Hafez (eds.); 7th ed). Blackwell Publishing.

Kuswati, \& Susilawati, T. (2016). Industri Sapi Potong. UB Press.

Montiel, F., \& Ahuja, C. (2005). Body condition and suckling as factors influencing the duration of postpartum anestrus in cattle: a review. Animal Reproduction Science, 85(1-2), 1-26. https://doi.or g/10.1016/j.anireprosci.2003.11.001

Noakes, D. E. (2001). Arthur's Veterinary Reproduction and Obstetrics. In Arthur's Veterinary Reproduction and Obstetrics (8th ed.). Saunders 1td. https://doi.org/10.1016/B978-0-70202556-3.X5001-4
Pradhan, R., \& Nakagoshi, N. (2008). Reproductive disorders in cattle due to nutritional status. Journal of International Development and Cooperation, 14(1), 45-66. https:// doi.org/10.15027/28498

Pryce, J. E., Coffey, M. P., \& Simm, G. (2001). The Relationship between body condition score and reproductive performance. Journal of Dairy Science, 84(6), 1508-1515. https://doi.org/10.31 68/jds.S0022-0302(01)70184-1

Roche, J. F. (2006). The effect of nutritional management of the dairy cow on reproductive efficiency. Animal Reproduction Science, 96(34), 282-296. https://doi.org/10.1016/ j.anireprosci.2006.08.007

Roelofs, J., López-Gatius, F., Hunter, R. H. F., van Eerdenburg, F. J. C. M., \& Hanzen, C. (2010). When is a cow in estrus? Clinical and practical aspects. Theriogenology, 74(3), 327-344. https://doi.org/10.1016/j.theriogenolo gy.2010.02.016

Royal, M. D., Darwash, A. O., Flint, A. P. F., Webb, R., Woolliams, J. A., \& Lamming, G. E. (2000). Declining fertility in dairy cattle: changes in traditional and endocrine parameters of fertility. Animal Science, 70(3), 487-501. https://doi.org/10.1017/S13 57729800051845

Saacke, R. G. (2008). Insemination factors related to timed $\mathrm{AI}$ in cattle. Theriogenology, 70(3), 479-484. https://doi.org/10.1016/j.theriogenolo gy.2008.04.015

Susilawati, T. (2013). Pedoman Inseminasi Buatan pada Ternak. UB Press.

Susilawati, Trinil, Fauzi, M. R., Suyadi, Kuswati, \& Yekti, A. P. A. (2018). The effects of estrous synchronizations by using PGF $2 \alpha$ on the conception rate on Brahman cross cow. Asian Journal of Microbiology, Biotechnology and Environmental Sciences, 20(3), 818-820.

Yekti, A.P.A, Susilawati, T., Ihsan, M. N., \& Wahjuningsih, S. (2017). Fisiologi 
Reproduksi Ternak (Dasar Manajemen Reproduksi). UB Press.

Yekti, Aulia Puspita Anugra, Kusumawati, E. D., Kuswati, K., Ridhowi, A., Sudarwati, H., Isnaini, N., \& Susilawati, T. (2018). Succesfull of Artificial Insemination by Using Chilled Semen on Brahman Cross Cows. Proceedings of the $1 s t$ International Conference in One Health (ICOH 2017), 221-226. https://doi.org/10.2991/icoh-17.2018.43 